\title{
Systematics and Extended Distribution of Metapenaeus elegans De Man, 1907 in Coastal Water of India
}

\author{
Angsuman Chanda* \\ Raja NL Khan Women's College, Midnapur West Bengal, India \\ *Corresponding author: Angsuman Chanda, Department of Zoology, Raja NL Khan Women's College, Midnapur, Paschim Medinipur-721102, West \\ Bengal, India
}

Submission: 望 May 12, 2018 ; Published: 望 May 26, 2018

\begin{abstract}
Present study reveals that the prawn Metapenaeus elegans is an established species. The species has been described from Menado, Celebes during "Siboga Expedition" by De Man. Silas and Muthu has reported the species first time from Andaman Sea of Indian water. Still date the species has been reported from Andaman water by several authors. During the present study the species has been recorded from Andhra Pradesh coastal water of India. As such present study extends the distribution range of the species up to coastal water of Indian main land.
\end{abstract}

Keywords: Metapenaeus elegans, Distribution, Andaman, Andhra Pradesh

\section{Introduction}

Prawn is the most valuable marine resource of many nation and contribute a lion share to the economy of the country. Exploitation of prawn resource from the seas around each country is playing increasingly significant role in furthering their national economy [1-4]. Recently, though there is some ecological hazard in prawn culture but due to high demand of prawn products among people, every nation is trying to grow their prawn production by culturing more and more prawn species found in their local population which is unknown but usable stocks and expansion of prawn fisheries and industries near coast line is rightly being given the maximum encouragement in the development programme of a nation. In India, with the introduction of mechanization and due to the development of efficient export industries, prawn fishery has substantially improved during last three decades.

The foreign exchange earnings by exporting of prawns and prawn products from the country have grown up considerably at present. In short, as in every prawn fisheries together with all the segments of the industry concerned with prawn products export are playing increasingly prominent role in the economy of the country. Due to this economic importance and the fact that penaeid prawns occur in a wide variety of ecosystem like marine, estuarine and back water habitats, knowledge on the ecology, feeding, reproduction, lifecycle, fecundity, prey predator relationship, behavior, population dynamics and fisheries potentials have vastly increased over the last three decades [5-9]. The knowledge on the prawn taxonomy is an essential prerequisite for their proper management and exploitation. Fabricius [10] is the pioneer worker on prawn taxonomy in Indian water. Some important contributions on the prawns of this region during nineteenth century were by Milne Edwards [11], Miers [12], Bate [13], Wood-Mason [14], Wood-Mason \& Alcock [15], Alcock \& Anderson [16,17]. Alcock $[7,18,19]$ \& George [20] was the taxonomist of 20th century who tried to make a comprehensive study on the penaeid taxonomy in Indian region. In late 20 th and early 21 st , there are so many taxonomic contributors on the group like Fischer \& Bianchi [21], Paulinose [22], Achuthankutty \& Parulekar [23], Reddy [24], Pathan \& Jalihal [25], Chanda \& Bhattacharya [26-30], Chanda \& Roy [31,32], Chanda [33-35], Kunju [36], Kurian \& Sebastean [37], Radhakrishnan et al. [38], etc are available valuable contribution for Indian water.

In spite of these work, there are some lacuna on the penaeid systematics and distribution of Indian region. So, present work is an attempt to fill up one of such lacuna found by the author on distribution of Metapenaeus elegans De Man, 1907. The species was previously recorded only from Andaman Sea by the above mentioned scientific works in Indian regions. Present work is the distributional range extension of the species from Andaman to Andhra Pradesh coast and its systematic study will certainly enrich our knowledge on the diversity of penaeid prawn in Indian coastal water. 


\section{Materials and Methods}

Present study is mainly based on the specimens preserved in the National Collection of the Zoological Survey of India, Kolkata, West Bengal, India, collected by different scientists and researcher of the organization. The materials preserved in rectified spirit (90\%) and body parts of taxonomic importance have been dissected and studied under a stereoscopic binocular microscope, if necessary. The detailed taxonomic history of the species have been furnished and also their diagnostic characters, distribution, taxonomic remarks have been furnished. In addition an attempt has been made to consult and cite an up to date literatures are included in the Reference Section. For all citations of taxon, author's name and year of publication has been given for easy searching of the respective literature.

\section{Systematics account}
A. Subphylum: Crustacea Brunnich, 1772
B. Class: Malacostraca Latreille, 1802
C. Subclass: Eumalacostraca Grobben,1892
D. Superorder: Eucarida Calman,1904
E. Order: Decapoda Latreille, 1802
F. Suborder: Dendrobranchiata Bate, 1888.
G. Super family: Penaeiodea Rafinesque-Schmaltz, 1815.
H. Family: Penaeidae Rafinesque - Schmaltz, 1815.
I. Genus: Metapenaeus Wood-Mason, 1891.

\section{Metapenaeus elegans De Man, 1907}

M. elegans was described by De Man [39] from Menado, Celebes during "Siboga Expedition". The species was first recorded from India by Silas \& Muthu [40]. A brief history of the species with special reference to Indian contributions has been given below. 1907 Metapenaeus elegans De Man, Notes Leyden Mus., 29(2): 130;
Silas \& Muthu, 1974, J Mar Biol Ass India, 18(1): 78-90. Jones 1976 [41], Proc Symp Crustacea 4: 1328-1340.

Type species: Metapenaeus elegans De Man, 1907, Notes Leyden Mus 29(2): 130.

Type Locality: Menado, Celebes.

\section{Material Examined}

15 males (30-58mm) and 16 females (30-60mm), ZSI Reg. No. C4892/2, Mypadu, Nellore, Andhra Pradesh, 31.8.1995, A Chanda.

\section{Diagnosis of the species (Figure 1)}

Dorsal portion of carapace and first abdominal segment is pubescence, sometimes body smooth; rostrum long extend beyond peduncle antennules, tip of rostrum slightly up tilted, armed with 9-12+1 dorsal teeth only; no toothless portion on rostrum; post rostral carina not reaching posterior margin of carapace; adrostral carina ending in between penultimate and second rostral tooth on carapace and sulcus behind epigastric tooth; epigastric tooth conspicuously separated from penultimate tooth of rostrum; antennal and hepatic spine prominent; postocular sulcus oblique to the horizontal axis of carapace, cervical sulcus marked prominently; hepatic sulcus descend vertically and then turn towards pterygostomian angle on carapace; pterygostonian angle blunt and rounded; branchio-cardiac carina prominent and jointed with hepatic spine of carapace; ischium of first pereopod with a sharp spine; in adult males merus of fifth periopod followed by a keel shaped tubercle; telson having no movable spine, has minute lateral row of spinules; antennular flagella equal; distomedian projection of median lobe of petasma is petaloid with a longitudinal groove at median portion, directed antero-laterally over distolateral projection of lateral lobe of petasma; anterior plate of thelycum tongue shaped, narrow posteriorly and wide anteriorly, a longitudinal groove present on midposterior part of anterior plate, guarded by two kidney shaped median lobs; lateral margin of posterior plate on sternite XIV raised upward and curved inward like ear flap.

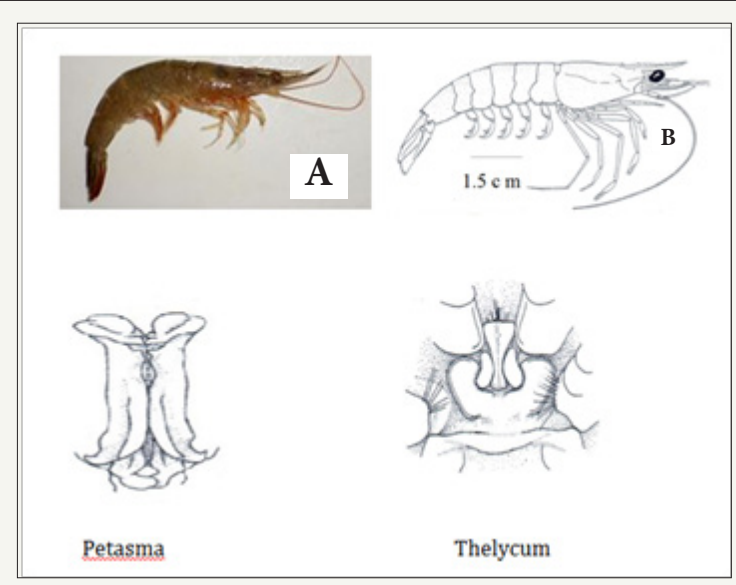

Figure 1: Metapenaeus elegans De Man (1907);

A: Color,

B: Line drawing. 


\section{Distribution}

India: Andaman Sea and Andhra Pradesh, east coast of India.

Elsewhere: Philippines; New Guinea; Fiji; Wallis; Futuna Island Sri Lanka; Malaysia; Borneo and Thailand.

\section{Conclusion}

All materials examined confer well with the description and illustrations of Hall $[42,43]$ except presence of a sharp ischial spine on first pereopod as observed also by Silas and Muthu [40] in their collections from Andaman Sea. Previous records reveal that the species has been reported only from Andaman Sea, India by several authors like Silas EG \& Muthu MS [40], George [20], Kurian \& Sebastean [37], Radhakrishnan EV et al. [38], Jones S [41] etc . During the present study the species is being first time recorded from Andhra Pradesh coastal water i.e., from coastal water of main land of India. Therefore, present work is the record of extended distribution for the species in Indian region and the work will certainly enrich our knowledge about the macro-faunal diversity in the coastal water of India. Simultaneously, systematic account for the species is the additional attribute in the present work for proper identification of the species.

\section{Acknowledgement}

Author is thankful to the Director, Zoological Survey of India for awarding a research fellowship during which the study has been done. Author is also thankful to Professor Tanmay Bhattacharya, Ex-Emeritus Professor of Zoology, Vidyasagar University, Midnapur, Paschim Medinipur, West Bengal for his valuable advice and guidance during the preparation of manuscript. Author thanks to anonymous reviewer and editorial board of journal named Examines in Marine Biology \& Oceanography for their valuable suggestions.

\section{References}

1. Kubo I (1949) Studies on penaeids of japanese and its adjacent waters. Tokyo College of Fisheries 36(1): 467.

2. Stimpson W (1858) Prodromus descriptionis animalium evertebratorum quae in expeditione ad oceanum pacificum sententrionalem a republica federata missa, cadwaladaro ringgold et Johanne Rodgers Ducibus observavit et descripsit. Proceedings of the Academy of Natural Sciences of Philadelphia 9: 216-221.

3. Holthuis LB (1955b) Crustaces Decapodes Macrures. Result Sci Exped Oceanogr Belge Atl Sud 3: 1-88.

4. Starobogatov YI (1972) Peneid (sem Peneidae Crustacea Decapoda) Tonkinskogo Zaliva Penaeidae (Crustacea Decapoda) of Tonking Gulf. Explor Fauna Seas 10: 359-415.

5. Holthuis LB (1980) FAO species catalogue vol.1 shrimps and prawns of the world. FAO Fisheries Synopsis 1: 271.

6. Burkenroad MD (1983) Natural classification of Dendobranchiata, with a key to recent genera. Crustacean Phylogeny 1: 279-290.

7. Alcock A (1905) A revision of the "Genus" Peneus with diagnoses of some new species and varieties. Annals and Magazine of Natural History 16: $508-532$
8. Hayashi KI (1992) Dendrobranchiata crustaceans from Japanese waters. Tokyo Seibutsu Kenkyusha 1:1-300.

9. Farfante IP, Kensley B (1997) Penaeoid and sergestoid shrimps and prawns of the world. Keys and diagnoses for the families and genera. Memoires du Museum National d'Histoire Naturel 175: 1-233.

10. Fabricius JC (1798) Supplementum Entomologiae systematicae: (Hafniae, apud Proft et Storch). p. 572.

11. Milne Edwards H (1837) Histoire naturelle des crustacés comprenant l'anatomie la physiologie et la classification de ces animaux. Librairie encyclopédique de Roret Paris 2: 556.

12. Miers EJ (1878) Notes on the penaeidae in the collection of the British Museum with descriptions of some new species. Proceedings of the Zoological Society of London pp. 289-310.

13. Bate CS (1888) Report on the crustacea macrura collected by H.M.S challenger during the years 1873-1876. Report Scientific Results Voyage Challenger 24: 1-942.

14. Wood Mason J (1891) Natural history notes from H.M. Marine Surveying Steamer 'Investigator'. Ann Mag nat Hist 7(6): 1-19.

15. Wood Mason J, Alcock A (1891) Natural history notes from HM. Indian marine survey steamer 'Investigator' commander RF Hoskyn RN commanding No 21 note on the results of the last season's deep-sea dredging. Ann Mag nat Hist 7: 1-19.

16. Alcock A, Anderson AR (1894) Natural history notes from HM. Indian marine survey steamer 'Investigator', commander CF Oldham RN commanding series 11 No 14 an account of the recent collection of deepsea crustacea from the Bay of Bengal and Laccadive Sea. J Asi Soc Bengal 63: 141-185.

17. Alcock A, Anderson AR (1899) Natural history notes from HM. Royal Indian marine survey ship 'Investigator' commander TH Heming RN commanding series III No 2 an account of the deep-sea crustacea dredged during the surveying-season of 1897-98. Ann Mag nat Hist 3(7): 278-292.

18. Alcock A (1901) A descriptive catalogue of the Indian deep-sea Crustacea Decapoda Macrura and Anomala, in the Indian Museum. pp. 1-286

19. Alcock A (1905) Catalogue of the Indian Decapod Crustacea in the collection of the Indian Museum part III Macrura. Fasciculus I the prawns of the peneus group. Indian Museum 19: 127.

20. George MJ (1979) Taxonomy of Indian prawns (Curstacea, Decapoda, Penaeidae) "in contribution to Marine Science" dedicated to Dr. CV Kurian pp. 21-59.

21. Fischer W, Bianchi G (1984) FAO Identification Sheets for Fishing Purposes. Western Indian Ocean (Fishing Area 51) 4.

22. Paulinose VT (1986) Larval and postlarval stages of Atypopenaeus Alcock (Decapoda, Penaeidae, Penaeinae) from Indian Ocean Mahasagar Bull Nat Inst Oceanogr 19(4): 257-264.

23. Achuthankutty CT, Parulekar AH (1986) Growth of penaeid prawns in Goa waters. Indian J mar Sci 15: 117-120.

24. Reddy KN (1995) Estuarine Ecosystem Series, Part 2: Hugli Matla Estuary. Zool Surv India 2: 119-215.

25. Pathan DI, Jalihal DR (1997) Proposed taxonomic revision of some important penaeid prawn genera (Crustacea, Decapoda) of Konkan coast (west coast of India). J Bombay Nat Hist Soc 94: 496-514.

26. Chanda A, Bhattacharya T (2002) Melicertus similis a new species of prawn Decapoda Penaeidae from India. J B Nat Hist Society 99: 495-498.

27. Chanda A, Bhattacharya T (2003) Fenneropenaeus Konkani a new species of prawn (Decapoda: Penaeidae) from Indian Coast. Sci and Cult 69: 229-230. 
28. Chanda A, Bhattacharya T (2004) A new species of the genus Parapenaeopsis Alcock 1901 Penaeoidea: Penaeidae from Orissa. India Proc Zool Soc Calcutta 57: 23-27.

29. Chanda A, Bhattacharya T (2009) Zoogeographic Distribution of Indian penaeidae proscidings of the International seminar on modern trends in biological sciences. Raja NL Khan Women College Midnapore West Bengal, India.

30. Chanda A, Bhattacharya T (2014) A systematic study on Indian records of Atypopenaeus Alcock 1905 with special reference to extended distribution of Atypopenaeus stenodactylus (Stimpson, 1860). Int J Sc Tech 2: 11-14.

31. Chanda A, Roy T (2004) Prawns of Gujarat Coast. Zool Surv India State Fauna Series 8 Fauna of Gujarat 8(2): 211-218.

32. Chanda A, Roy T (2005) CRUSTACEA DECAPODA PANAEOIDEA. Zool Surv India State Fauna Series 5 Fauna of Andhra Pradesh 5: 537-550.

33. Chanda A (2014) First Record of Two Australian Species One under Metapenaeopsis and Another under Metapenaeus from Indian Water their diagnosis and distribution. J Ento Zoo Studies 2(4): 18-20.

34. Chanda A (2014) Revision to the diagnostic characters of Trachypenaeopsis minicoyensis Thomas1972. Int J Sc Tech Res 3(8): 369-370.

35. Chanda A (2015) A study on the Indian records of the species under genus Megokris Perez Farfante \& Kensley 1997. International Journal of Current Research 7(4): 14920-14923.
36. Kunju MM (1967) Observations on the prawn fisheries of Maharashtra coast. Proc Symp Crustacea 4: 1382-1397.

37. Kurian, Sebastian (1993) Prawns and Prawn Fisheries of India. Hindustan publishing corporation, Delhi, India, pp. 1-280.

38. Radhakrishnan EV (2012) Prawn fauna (Crustacea: Decapoda) of India - An annotated checklist of the Penaeoid, Sergestoid, Stenopodid and Caridean prawns. J Mar Biol Ass India 54 (1): 50-72

39. De Man JG (1907) Diagnoses of new species of macrurous Decapod Crustacea from Siboga Expedition. Notes Leiden Mus 29(2): 127-147.

40. Silas EG, Muthu MS (1974) On a new species of penaeid prawn of the genus Metapenaeus Wood-Mason and Alcock, from the Andamans. J mar biol Ass India 16(2): 645-648.

41. Jones S (1967) Crustacean fishery resources of India. Proc Symp Crustacea 4: 1328-1340.

42. Hall DNF (1956) The Malayan Penaeidae (Crustacea, Decapoda). Part I. Introductory notes on the species of the genera Solenocera, Penaeus and Metapenaeus Bull Raffles Mus 27: 68-70.

43. Hall DNF (1962) Observations on the taxonomy and biology of some Indo-West Pacific Penaeidae (Crustacea, Decapoda). Fish Publ Col Londo 17: 1-229.
Creative Commons Attribution 4.0 International License

For possible submissions Click Here

\section{Submit Article}

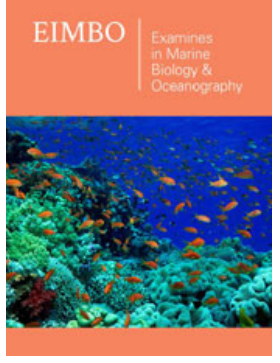

Examines in Marine Biology \& Oceanography

\section{Benefits of Publishing with us}

- High-level peer review and editorial services

- Freely accessible online immediately upon publication

- Authors retain the copyright to their work

- Licensing it under a Creative Commons license

- Visibility through different online platforms 